\title{
CHARACTER EDUCATION BY COMPREHENSIVE APPROACH IN LOCAL HISTORY ON THE LOCAL COMMUNITY OF MERAPI'S SLOPE IN SLEMAN YOGYAKARTA
}

\author{
Muhammad Syaifulloh \\ syaifullohm22@yahoo.com \\ Post Graduate Student in State University of Yogyakarta, Indonesia
}

\begin{abstract}
Current conditions with the past are different. The character education strategy that has developed so far follows the development of modern times but ignores the local side of genius and local wisdom in the local history of its people. The theory of Kirschenbaum's comprehensive approach can provide a new alternative in developing local history-based character education. Javanese rural communities on the slopes of Mount Merapi have local character values that can be developed in an effort to strengthen national identity and national character building.
\end{abstract}

Keywords: Character Education, Comprehensive Approach, Local History, and the Java Rural Community of Mount Merapi.

\section{INTRODUCTION}

The integration of character education in the Indonesian education curriculum, starting from basic education institutions to tertiary institutions, has not yet appeared. College as the last gate is considered not able to bring meaningful change to the community. So that an integrated and comprehensive effort is needed to overcome this.

Integration of character education in various materials, especially local history which has material that has a correlation with character education because it contains local wisdom, local genius or local knowledge to be the command in the integration of character education in other materials. For example, Bahri's research[1] shows that local history in South Sulawesi has a variety of character values contained in lontara, lontara said, pappaseng and other local historical sources are invaluable wealth that can be a source of history based on character education.

Another study that covers the realm of local history is the Dongkrak (Dongeng jeung Kaulinan Barudak) as an anti-corruption character education strategy in early childhood. Jack's strategy uses fairy tales and beliefs to instill the values of honesty, discipline, hard work, responsibility, and humility in early childhood. The results of this study indicate that the class that has the strategy of Dongkrak has significant results in understanding the character values. Therefore, the Dongkrak strategy is very effective for teaching character education for early childhood[2]

Planting Character Education through Alms Earth Traditions as Indigenous Local Wisdom Kedungadem Bojonegoro Community in East Java. This tradition is a form of celebration for the expression of people's gratitude to God from the abundance of grace and sustenance that has been given (the harvest). The expression of gratitude transforms into a traditional heritage from the ancestors that must be maintained from year to year. So that there 
are a lot of values and messages contained therein, not least the planting of character education in children. Because character education is one of the goals of the intended cultural preservation. Good character, related to knowing the good, loving the good, and doing good (acting the good). So how can these three points be manifested in everyday life[3].

The people on the slopes of Mount Merapi also have values in local history in the form of various local cultures such as oral stories about the history of the village, the ceremony of Merapi harbor, the ritual ceremony of the traditional Pangesti Jawi ceremony, kenduri, and others. Values that uphold historical values as a tool of value education in their society. Various kinds of local culture give dark a great deal in recognizing local identity and can strengthen identity.

This issue of identity, in the peer culture group, teenagers find their social identity. Through peer groups, teenagers hang out, adapt and explore positive potentials in themselves. This positive potential will be developed in order to strengthen its identity so as to bring about a person of character. Peer culture group as one approach that can be done in order to construct character values in adolescents. The peer group culture approach developed a culture of equality (egalitarian), criticality, solidarity, and social solidarity. So that various cultures learned by youth through peer groups will shape adolescent characters that are adaptive to their social environment[4].

A good education is an education based on morality and character/personality. Today, education requires more than learning about morality and its true character is the integration of morality and character in behavior that can be justified according to universal moral principles[5]. What character education method will be used can influence the results, so Thomas Lickona that character education must pay attention to the dimensions of knowledge, feelings, and actions as well as Nel Noddings's proposal regarding the importance of moral communities that pay attention to four elements (modeling, dialogue, practice of virtue, and affirmation) can be an important contribution to the implementation of character education today.

Character education is a conscious and systematic effort to instill and familiarize certain characters with students in certain moral environments or communities by paying attention to the importance of knowledge, effective dimensions and actions. Affective dimensions and actions can be fostered through conditions of modeling, dialogue, and affirmation. While knowledge allows the implementation of character education that is not only aware of certain characters that must be accustomed to but also critical thinking to distance themselves from character education, not for the benefit of students.

The extent to which the moral community is free from certain ideological, economic, or political interests, especially in relation to the formulation of character that is shared morality, needs a new strategy[5]. Local history lessons serve as one of the strategic components in the student character development system, as a medium for inheriting local historical values as a bridge between the real world and the school world, and as a student facilitator in implementing the character values they obtain.

Therefore, this article attempts to explain about; (1) how is the concept of character education in the learning of local history, (2) a comprehensive approach to learning local history, (3) a local history learning model based on a comprehensive approach and what character values can be applied in learning local history.

\section{RESEARCH METHODS}

This study uses qualitative research methods with a fixed case study strategy. Data sources used are informants, places and events, and documents. Data collection techniques use 
direct observation techniques, in-depth interviews, and document studies. The sampling technique used is purposive sampling. Data validity uses triangulation and data analysis techniques using interactive analysis techniques.

\section{RESULTS AND DISCUSSION}

\section{A. The concept of Character Education in Local History Learning}

According to Wasino[6], local history contains important values to be understood by students, such as patriotism or patriotism, tolerance or mutual respect for differences around, etc. The process of learning history as a process of internalization of values in which these values are contained in local history. Various local historical events on the slopes of Mount Merapi vary and leave a historical trail. One example of local history that can provide character education is the story of the escapees of officials of the Majapahit kingdom to the slopes of Mount Merapi.

Local history which is only different from the spatial scope in National history is considered important to be taught in schools considering the local identity of today's young generation is increasingly eroded by the flow of globalization and in order to foster a sense of pride in the region's identity, so that today's young generation is expected to be able to realize the high and diverse local culture owned by the Indonesian Nation. In addition, local history can also train students 'critical power towards history, increase students' appreciation of historic relics, and finally be able to foster awareness in students as part of the Indonesian nation that has a sense of pride and love for the country[6].

In order to have a strong appeal, local history needs to be developed in accordance with demands and needs. For example, a teacher can develop local history in a number of ways, including local history presented in an educational perspective, draw relationships from local history with national history, conduct environmental exploration activities, special studies on history in the surrounding environment. However, in learning local history also has several problems that must be the teacher's attention, namely that local history should not occupy a greater portion of national history. Local history is complimentary.

In the teaching of local history that emphasizes the delivery of character values that are important for the lives of students. Concern over the emergence of excessive ethnocentrism in the learning of local history due to the perspective that sometimes differs between local history and national history is indeed a problem for history teachers who often confuse themselves in learning in school. On the one hand, there is a curriculum that becomes a guide, while on the other hand there is a local history that needs to be taught in order to introduce local identity to students. This confirms that these differences actually become opportunities to train students' critical power. Teachers can use the problem-based learning method to see how students perceive one event from two different things so as to be able to foster awareness that locality is able to become a path to nationalism.

Some of these problems with their main goals and priorities are conveying values and providing strong binding power, a more comprehensive strategy is needed with several supporting components. A comprehensive perspective can be applied to learning local history by not ignoring local wisdom such as those on the slopes of Mount Merapi. Various local historical stories on the slopes of Merapi have character values that can be exemplary and inspiring and reflective in an effort to develop effective local history learning.

\section{B. Comprehensive Approach to Local History Learning}

A comprehensive approach is a new approach that includes multi-approach or multiperspective in looking at character education. A comprehensive approach is a comprehensive 
approach, taking into account the interrelations of various aspects that are mutually integrated. Then character education is an effort in the formation of ethics, a sense of caring, and responsible in the way of teaching and application. Character education using a comprehensive approach provides supporting efforts in the implementation of character building. Because with this approach, there is a mutual relationship between components in character education.

Based on a circle or a comprehensive character approach scheme of character education by Thomas Lickona, that character comes from a sense of responsibility and respect. Then the character is formed because of it; (1) Knowing the character; whether or not the character he already knows, (2) Feeling the character; has begun to feel and embedded these characters, and (3) Actions or implementation of these characters[7].

The comprehensive term in value education covers several aspects. First, the content of value education must be comprehensive, which includes all issues related to personal values to issues that are ethics in general. Second, the value education method must also be comprehensive, which includes inclusion (inclusion), giving an exemplary example, facilitating and developing academic and social skills. Third, value education should occur in the whole process of education in schools. Not only in the learning process in the classroom but also in extracurricular activities, in the process of guidance and counseling and all aspects of life. Fourth, value education should also be through people's lives. Apart from the family, namely parents, but also from organizations in the community or religious institutions such as the Alqur'an Education Park (TPA) or Taman Pendidikan Qur'an (TPQ), so all need to participate in the cultivation of value education to improve the character and moral generation nation[8].

Furthermore, in value education must also be supported by students who lead to individuality. Then with holistic self-development, namely aspects of intellectual, emotional and spiritual intelligence. Likewise, there are four approaches that are considered as the main movement in constructive value education, namely 1) realization of value, 2) character education (character), 3) citizenship education and 4) moral education[8].

In connection with local history learning, character education is taught primarily through oral or inheritance stories. This can be seen in the habits of the village people about bedtime stories, or local stories that are used as the main model in the process of education in community life. The family becomes the first place of value education with the aim of being a socially good child in community life. Local history remains an effective tool in teaching successive generations in rural communities.

Villagers on the slopes of Mount Merapi are still very much preserving various local history stories. The open nature of society without losing the character of the local community becomes an extraordinary attraction. The local concept is highly upheld with a variety of external influences that actually bring wealth to the local culture of the community. The process of cultural acculturation is increasingly evident in this region. Interestingly, this starts from how village elders carry out the process of education to their offspring with a very flexible and cultural education process.

The process of value education is included in several kejawen teachings by focusing on goals and following the times. The concept of value education from time to time is ideal and still in accordance with the development of modern-day adults. This has become reasonable because the basic moral values of society are upholding the values of harmony and harmony in life. So that the educational process is very strong in culture, flexible and imprinted in social life. 
Character education by utilizing local history is very much in line with Mac Affe's thinking, namely local history is the study of regional changes in society. The viewpoint in the local area allows the creation of a multi-perspective configuration in the study of local history. Thus the approach angle to the study of history from each region can vary, namely:

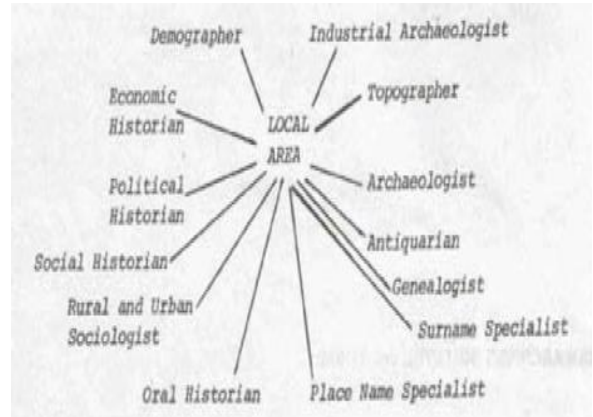

Figure 1. Variations in the Viewpoint of Local History Studies[9]

\section{Local History Learning Model Based on Comprehensive Approach}

The purpose of applying local history to history learning is (1) learning materials will be more easily absorbed by students, (2) learning resources in the area can be more easily utilized for educational purposes, (3) students are more familiar with environmental conditions, (4) students can increase knowledge about the area, (5) students can help themselves and their parents in order to meet their needs, (6) learners can apply the knowledge, attitudes, and skills learned to solve problems found around them, (7) participants students become familiar with their environment[10], and students are more creative, innovative, patriotic, and love the homeland.

Observing the increasingly complex development of society, it is necessary to have a local-standard curriculum with international standards, because the development of the history curriculum is inseparable from external and internal factors. The national curriculum which is compiled based on basic competencies in the form of International Standards will provide a great opportunity for the regions to develop local content in history learning, in accordance with the characteristics of each region.

In developing a local history curriculum, it can be packaged by describing and adding study material from history lessons. To be able to develop local history content properly it is necessary to continue to use the approaches that apply in national history, namely factual, processual, problem-solving, and thematic. The thematic approach requires the development of social history, economic history, plantation history, and the history of civilization, which can be chosen according to the conditions of each region.

The development of learning about local history needs to look at the direction of Indonesian centric historical material, the direction of the history of the Indonesian nation which was originally determined by the elites/rulers, leading to a historical movement that is not only determined by the rulers, but by the Indonesian people. In facing the challenges of history learning, this is how the role of history educators really determines other than as curriculum implementers and historical curriculum developers, they must also be able to conduct local history studies around their environment.

Integration of local history is a historical loading in a limited scope covering a particular location. The need for local history loading because to know greater unity, even 
smaller parts must be understood well. Often things that exist at the national level can only be understood well if we understand well the development at the local level. The development of writing that is national in nature as it has been often lacked meaning for certain people, especially those related to the history of its own territory[11].

Learning local history, bringing students in an effort to remember the past experiences of their community by looking at the present situation, can even project opportunities and challenges in the future. In learning local history students will get many examples and experiences from various levels of the development of the community environment, including the current situation. Thus, they will more easily grasp the concept of change which is the key link between the past, the present, and the future.

When related to J. Bruner's theory and in relation to the concepts of the process approach, local history learning strongly supports the principle of developing students' abilities to think actively, creatively and structurally conceptually. Almost all principles in the context of active student learning are very relevant to learning activities that are local history. In accordance with the nature of the material and sources of local history, students will be encouraged to be more sensitive to the environment.

Furthermore related to these problems, Douch[12] proposed three models of local history learning. First, historical educators only take examples of local events to give a more lively illustration of the national history and history of the world being taught. Here clearly there will be no problem for businesses that link local history with the applicable history learning curriculum because there is no time allocation that has been provided and there are no special activities outside the classroom that must be done by educators and students[13].

Second, it is carried out in the form of environmental exploration activities. Here there is an effort to give a more tangible portion of the learning activities of students with historical activities outside the classroom. In this form, students in addition to learning history in class, are also invited to the environment around the school to observe historical sources directly and collect historical data. The aspects observed are not solely in the form of history in the sequence of events, but also various aspects of life that are related such as geography, socio-economics, folklore, and agriculture.

Third, a special study of various historical aspects in the environment of students. Students are organized to follow procedures such as those carried out by professional researchers, ranging from topic selection, planning, how to make data analysis to preparing study reports.

Based on the opinion of Douch[12], a more comprehensive approach can be carried out while still being adjusted to the conditions of each region. The concept of locality is highlighted because of its own uniqueness, its own advantages, and disadvantages as well as different problems and solutions. Thus comprehensive comprehension is very important to be the basis of the study of how to teach local history[10].

The development of a local history learning model also considers effective learning resources, namely study material (written relics and sources about history). Student ability and professional ability of teachers in managing teaching and learning activities. The professional skills of teachers that can be developed in the learning process are writing, dramatizing, as well as other creative abilities to be explored. Local history learning aims to increase historical awareness with indicators of understanding historical material, appreciation, change, and views on history. In order to achieve a maximum increase in history, several approaches to history learning are needed.

Learning models in local history learning that can support the development of historical awareness such as picture studies, study documents, plays, historical tours and study 
maps. The discovery of the right historical learning model is not only useful for material acceptance but also the quality of students or graduates. It is hoped that with the discovery of the innovation model in local history education so that the material is more interesting and the delivery of historical education is not monotonous in the classroom.

The development of local history learning models will serve to improve competency standards to understand and appreciate the objects and heritage of global history and culture based on an understanding of cultural, geographical and historical context. History learning needs to use various models that have the potential to add insight and context to learning and improve learning outcomes. In teaching local history, students will get examples and experiences from various levels of the development of the community's environment. In short, they will more easily grasp the concept of time or development which is the key to connecting the past, past, and future according to the concept of history that combines three dimensions.

\section{What Character Values can be applied in Local History Learning}

Local history has different stories from each place. Therefore a place with another place possesses various and varied similarities and differences. Knowing local history with different values can become a model in developing local history learning strategies. Exploration of character values in local history must also be a major concern. With a variety of different languages, different histories, and different cultural cultures, of course, has a wealth of values that are local, national and even universal.

Character values contained in the local history of the people of the slopes of Mount Merapi include:

1. Alignment Value

This value is evident in the conception of the Javanese cosmological relationship which is the belief of the people on the slopes of Mount Merapi. The attitude of balance and mutual care is a benchmark for the character of the local community. This local reality is also conditioned by deeper beliefs related to mental representations of mountains where world representation is centered on Mount Merapi[14].

The close relationship between the surrounding creatures embodies the importance of tolerance and mutual respect among them. Not only to fellow humans, but also all beings who are in the location of both inanimate objects and living things. Inanimate objects for local people are not physically dead but they live to fill and give to each other as Mount Merapi gives an abundant gift of fortune.

2. Religious and religious values

This value indicates that the historical tempo of time on the slopes of Mount Merapi has occurred acculturation of various kinds of religion, religion, and trust with syncretization. Mixing trust gives a distinctive and attractive color and extraordinary appeal. The characteristic nature of this belief forms an ancient trusty color which gives a clue how high the belief is.

The discovery of ancient manuscripts in this location proves that there was a process of copying and the scientific process of students and even teachers who were doing my education. Buddhist priests pioneered the creation and writing of excellent historical and literary books. In fact, this book is now a new paradigm of literary writing, mostly from previous writers[15].

3. Creative Value

This value can be examined from a story and some relics as a form of local cultural results. During the Islamic Mataram period based in Kota Gede, this region was included in the territory of the Great State. In this period, this region found a cultural result such as 
the pathok of the country, Chinese ceramics and the relics of the "mystery" grave of Jumadil Kubro, giving news about the spread of Islam on the slopes of Mount Merapi precisely in the Turgo hill area. That said, this tomb has a close relationship with other grave relics on the slopes of Merapi precisely in the Wonolelo area, namely the Great Wonolelo ki tomb[16].

Not only that, this region still has some legacy of the past which is full of artistic and creative values that are capable of building architectural art such as temples. The discovery of the Ganesha temple and the like found in the area of the Indonesian Islamic University on Jl. Kaliurang km 14, the slopes of Mount Merapi, is a silent witness to the relics of the ancient civilization. the discovery of traces of temple construction is also found in many parts of the slopes of Mount Merapi stretching from end to end.

4. The value of struggle and love of the country

These values can be extracted from local history which leaves behind a historical story in the form of ancestral struggle in the time of the physical revolution. During the period of the physical revolution, this area proved to be the field of guerrillas of the freedom fighters. Potential locations in carrying out brilliant strategies against Dutch colonialism. Relics such as the inscriptions in Brayut, Cebongan, and Rejodani were witnesses of the monk battlefield between Republican fighters and Dutch colonials driven from guerrilla areas on the slopes of Merapi. Thus, on the slopes of Mount Merapi, this area is also a solid area of defense for Republican fighters[17].

5. Humanistic Value

This kind of value turns out to occur also on the slopes of Mount Merapi which is indeed a location that has an attraction. This value is the most important lesson in the whole humanity of the world towards the dark side of human life. This can be examined by local historians who tell about savage killings and rebellions. Boyolali Institute of Social Transformation Studies (LKTS), Central Java, has conducted research to explore the facts surrounding the G30S 1965 incident.

LKTS found that in Boyolali, violence only occurred around the slopes of Merapi and Merbabu, which later earned the nickname Merapi Merbabu Complex (MMC). MMC groups often commit crimes, such as robberies to kill people living around the two mountains[18].

6. Caring Value

This value is in accordance with the development of a better direction. During the New Order to the reform era, the slopes of Mount Merapi had become a potential observatory and tourism area. Mount Merapi is a prima donna that continues to have an appeal for the diggers and for everyone in the world. Factors for the development of the tourism environment, ecotourism and the development of modern science are the starting points for economic growth in the local communities of the slopes of Mount Merapi.

\section{CONCLUSION}

Character education is an obligation. Local history is the right place to instill character education, both family, school and community because there are various potential learning values. The aim of character education is to make civilized society and have a noble mind so that the concept of a comprehensive approach that emphasizes multiperspective is very appropriate and becomes the right alternative.

Local history learning model based on Comprehensive Approach can be a new alternative in overcoming the problems of declining current character, both local, national and international. Character values in local history can be explored in depth with studies of local 
history studies in history learning. All elements and strategies of local history learning can be very effective by utilizing a comprehensive approach.

The slope communities of Mount Merapi have traces of local history that can be used as local content in history learning. Character values in the local history of the Mount Merapi community such as harmony values, religious values, humanist values, creative values, struggle values and nationalism, and social environmental values can contribute greatly to developing a comprehensive history of learning based on Comprehensive Approach.

\section{ACKNOWLEDGEMENT}

Thank you very much to the villagers on the slopes of Mount Merapi, especially the elders, elders, village officials, residents of the village of Hargobinangun Pakem, Purwobinangun village Pakem and Kepuharjo Village Cangkringan for all the assistance we cannot mention one by one, so much so that this research can be completed and can be published.

\section{BIBLIOGRAPHY}

[1] Bahri, "Pendidikan Ilmu-Ilmu Sosial Membentuk Karakter Bangsa Dalam Rangka Daya Saing Global," in Seminar Nasional diterbitkan oleh Fakultas Ilmu Sosial, 2016.

[2] A. N. P. Dinar Nurinten, D.M Alhamuddin, "Kearifan Lokal Sebagai Media Pendidikan Karakter Antikorupsi pada Anak Usia Dini Melalui Strategi Dongkrak," Integritas, vol. 2 Nomor 1, 2016.

[3] S. Anam, "Penanaman Pendidikan Karakter Melalui Tradisi Sedekah Bumi sebagai Kearifan Lokal Adat Masyarakat Kedungadem Bojonegoro Jawa Timur," J. TAPiS, vol. 16, No. 01, 2016.

[4] A. Imron, "Mengkonstruksi Nilai-nilai Karakter Remajamelalui Pendekatan Peer Group Culture," in Proseding Seminar Nasional Dalam Rangka Dies Natalis Emas ke 50, 2014.

[5] Y. Jena, "Pendekatan Integratif Dalam Pendidikan Karakter," RESPONS PPE-UNIKA ATMA JAYA Jakarta, vol. 21 No. 02, pp. 251-275, 2016.

[6] Wasino, "Pokok-Pokok Pikiran untuk Penulisan Sejarah Lokal. Makalah Sarasehan Koordinasi dan Curah Pendapat Penguatan Sejarah Lokal untuk Meningkatkan Wawasan Kebangsaan Deputi Menko Kesra Bidang Koordinasi Kebudayaan, Pariwisata, Pemuda dan Olah Raga. Patra Jasa ," Semarang, 2009.

[7] T. Lickona, Educating for character, how our schools can teach respect. Respect and Responsibility. New York: Bantam Books, 1992.

[8] D. Zuchdi, Humanisasi Pendidikan, Menemukan Kembali Pendidikan yang Manusiawi. Jakarta: Bumi Aksara, 2008.

[9] M. A. Richard, Table Tennis: Steps to Success. Human Kinetics, 2012.

[10] I. G. Widja, Sejarah Lokal Suatu Perspektif Dalam Pengajaran Sejarah. Jakarta: Departemen Pendidikan dan Kebudayaan, 1989.

[11] A. . Lapian, Memperluas Cakrawala Melalui Sejarah Lokal, Prisma No. Jakarta: LP3ES, 1980.

[12] R. Douch, Local History and the Teacher. London: Routledge and Kegan, 1967.

[13] R. Fauzan, "Penerapan Model Pembelajaran Living History Dalam Materi Sejarah Lokal Geger Cilegon 1888 Sebagai Upaya Membangun Nilai Patriotisme Siswa," J. Pendidik. dan Sej. Candrasangkala, 2013.

[14] Koentjaraningrat, Kebudayaan Jawa. Jakarta: Balai Pustaka, 1994. 
[15] I. K. Wiryamartana, Arjunawiwaha. transformasi teks Jawa kuna lewat tanggapan dan penciptaan di lingkungan sastra Jawa. Yogyakarta: Duta Wacana University press, 1990.

[16] T. L. Sasongko, Manusia Jawa dan Gunung Merapi: Persepsi dan Kepercayaanya. Yogyakarta: UGM Press, 1991.

[17] A. Tashadi, et, Kabupaten Sleman dalam Perjalanan Sejarah. Yogyakarta: Bagian Humas Sekretariat Daerah Kabupaten Sleman, 2002.

[18] A. Rafiq, Kisah G 30S 1965 dan harmoni yang koyak di lereng Merapi. Boyolali: LKTS, 2015. 